\title{
材料の表面と疲労強度に関する二，三の問題*
}

遠藤 吉 郎**

\section{On Fatigue Properties Affected by Surface Conditions of Materials}

by

\section{Kichiro ENDO}

(Faculty of Engineering, Kyoto University, Kyoto)

\section{1 緒}

\section{言}

表面工学の研究は種々の化学反応に大きく貢献して きたが，材料の変形能，強度に関する分野でも注目さ れてきはじめた，金属の摩擦，疲労は表面の影響の大 きい現象であり，表面の物理的，化学的状態の影響は 静的な場合より大きいととが考えられる。吸着より窝 食に進むと，疲労強度に及ぼす影響はいっそうはなは だしくなる，表面，あるいはふん囲気は疲労き裂の発 生だけでなく，その進展にも影響し，油が疲学強度に 及ぼす効果は実際的な意味ももっている。

ころがり接触によるピッチングは表面疲労の現像で あるが，さらにすべり摩擦による摩耗も一種の表面疲 労と考えられる場合が多く，その他エロージョンなど を含めて，表面損傷には共通した性質がみられ，表面 工学の一分野として興味がもたれる。ここには上記の 各事項について概説する。したがって表面仕上，加工 層，残留応力など，表面の機械的性質との関連は別に 讓りたい.

\section{2 表面エネルギと強度}

金属の表面エネルギはその強度に影響をもつ，液体 の表面エネルギは表面張力より知りうるが，固体にお いてはその測定が困難である。ぜい性材料ではへき開 に要する仕事から測定されるものがあるが，ふん囲気 の吸着に大きく影響される。また，溶態で表面張力を 測定し，凝固後の温度低下に対して適当に補正するこ とが行なわれるが，正確でなく，かつ金属固有の因子 がはいっててない，とのように，表面エネルギの絶対 值を知ることは困難であるが，その相対的変化が固体 の強度に種々の影響をもつてとが知られている。

* 原稿受理 昭和 42 年 6 月 15 日

** 正 会 員 京都大学工学部 京都市左亲区吉田本町
Griffith がき裂の進展によって開放されるエネルギ と，新しいき裂面を作るに要する表面エネルギとのつ りあいより，ぜい性材料のき裂の進展に対する条件を 求めたのは有名である，砂を微細化するに必要な仕事 には，砂の表面積増大による表面エネルギが含まれて いる．前者の大部分は塑性仕事として，熱損失になる と考えられるが，なお，両者の間にほぼ比例関係が認 められたととより，乙の考光方は粘性材料にも適用で きよう。ささら表面は変形能にも影響をもつ。たとえ ば，加工を受けた種々の材料のかたさ $H$ と表面エネル ギ $と$ と間にはFig. 1のように, $\gamma \propto H^{1 / 3}$ の関係が涩め

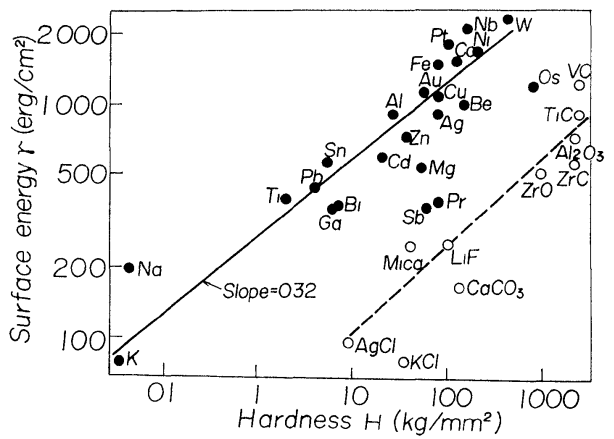

Fig. 1. Surface energy at the melting point against hardness at room temperature ${ }^{1)}$.

られている。

吸着によって表面エネルギが低下するとともに，機 械的性質に変化がみられる。たとえば，ガラスの破壊 遅れの現象は空中の $\mathrm{CO}_{2}$, 特に水蒸気の吸着のためで あって，ガラスをさきにベーキングして吸着ふん囲気 を取り去っておいて，真空中で試験するときは，破壊 の遅れがみられなくなる。また，単結晶では特に明か 
であるが，多結晶金属においても，無極性の油中で引 張るときより，オレイン酸その他の有極性の脂肪酸， アルコールなどを微量混ぜて吸着を強くさせると，降 伏点, 加工硬化係数が低下し, すべり帯の寸法が小さ くなる。乙れを Rebinder 効果と称するが，乙の効 果の結果，Fig. 2 にみるように，脂肪酸の含有によっ

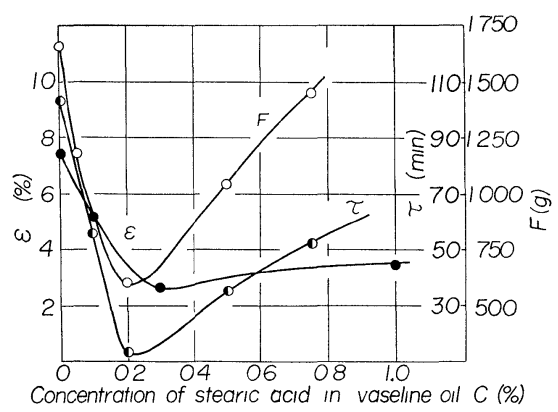

$\varepsilon$ : Rupture elongation of lead strips $(P=300 \mathrm{~g})$

$\tau$ : Rupture time of lead strips $(P=300 \mathrm{~g})$

$F$ : Static frictional force for steel-lead $\left(P=44 \mathrm{~kg} / \mathrm{cm}^{2}\right)$

Fig. 2. Effects of concentration of fatty acid in vaseline on mechanical strengths ${ }^{2}$.

て，細線のクリープ試験におけるラプチャ時間 $\tau$, ラ プチャ伸びをが低下し，摩擦力 $F$ も低下するといわれ ている. 摩擦力は二面の局部的に凝着した部分のせん 断に要する力であるので, 吸着によって表面層のせん 断抵抗が減少したためと考光られる。

表面エネルギは界面電位によっても変化する。すな わち，無電荷の状態より正負どちらにでも電荷を与兄 ると，表面エネルギは低下する。乙れに伴ってかたさ が変化する。 Fig. 3 亿 $1 \mathrm{~N} の \mathrm{Na}_{2} \mathrm{SO}_{4}$ 液中における

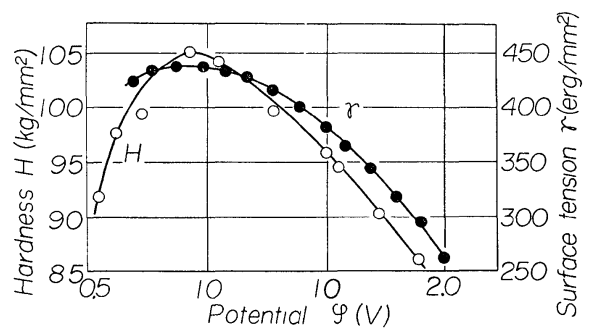

$H$ : Hardness of thallum in $1 \mathrm{~N}$. $\mathrm{Na}_{2} \mathrm{SO}_{4}$

$\gamma$ : Surface tension of thallium amalgam in $1 \mathrm{~N} . \mathrm{Na}_{2} \mathrm{SO}_{4}$

Fig. 3. Hardness and surface tension against potential drop ${ }^{2}$.

$\mathrm{T} 1$ のかたさと, タリウム・アマルガムの表面張力の 電位による変化を示すように，よく傾向が一致してい る. また, Fig. 4 に Pb の $5 \mathrm{hr}$ 後のクリープ変形 を示すように，電荷によってひずみが増大し，ひずみ が最小になる電位を有する。図でカソード側のみが示 されているのは，アノード側では表面に酸化物を生ず るためである。ささらに電解液中に脂肪酸, アルコール

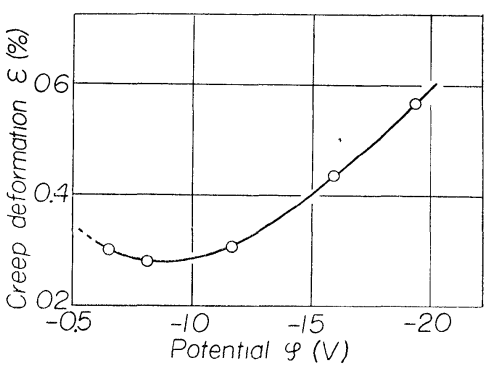

Fig. 4. Creep deformation of lead crystal against potential drop in $0.1 \mathrm{~N}$. $\mathrm{Na}_{2} \mathrm{SO}_{4}{ }^{2}$.

などの活性剤を少量混ぜると， $H_{\text {max }}$ は低下し， $\varepsilon は$ 増大している。

摩擦力もさきに述へた理由から界面電圧によって変 化する．Pt を希硫酸につけた場合の電極電位と摩擦 の関係としてFig. 5 が得られている. 酸素も水素もデ

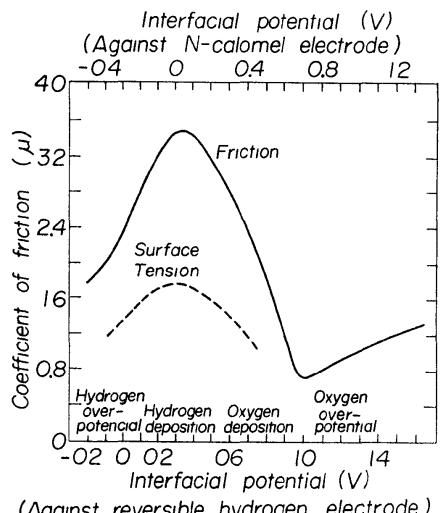

Fig. 5. Effect of interfacial potential on friction of platinum-platinum in $0.1 \mathrm{~N} . \mathrm{H}_{2} \mathrm{SO}_{4}{ }^{3}$.

ポジットしない電位で表面張力および摩擦は最高にな り，ての場合表面損鹪も最大であった。

金属の加工面は見掛け上，外部からエネルギを与光 ないでも電子を放射し，吸着を促進するととがある。

この Kramer 効果は金属切削における切削液の影響に もみられ，ある種の有機化合物は切削新生面の電子に よって金属面と反応する。潤滑油中の脂肪酸は研削や 摩擦された新生面の電子放射によって，その吸着が促 進され，せっけん生成が激しくなる。金属を水中で切 削すると，新生した金属面は電子のため周囲の水と酸 素を反応させて $\mathrm{H}_{2} \mathrm{O}_{2}$ 亿変化させるが，乙の現象は変 形によるすべり帯またはき裂にもみられる，Al 合金 その他の疲学試験片に透明テープをはって, 生ずるあ わより疲労き裂の観察が行なわれている。

以上述べたような種々の表面の影響は，断面に比べ て表面積の大きいとき著しくなるのは当然であるが， 疲労のように表面またはき裂先端が重要なときや，摩 
擦，摩耗その他の表面現象に対して特に影響が大きい と考兊られる。

\section{3 疲労強度とふん囲気}

真空中の疲労強度は空中より高いてとが知られてい るが，その程度は真空度に左右される， $\mathrm{Al}, \mathrm{Cu}, \mathrm{Ni}$ その他で試験された結果を総合すると, 破断繰返し数 $N$ と気圧 $p$ の間には両対数目盛で直線になる結果と,

Fig. 6 にみるように $10^{-3} \sim 10^{-4}$ torr で水平部がでる

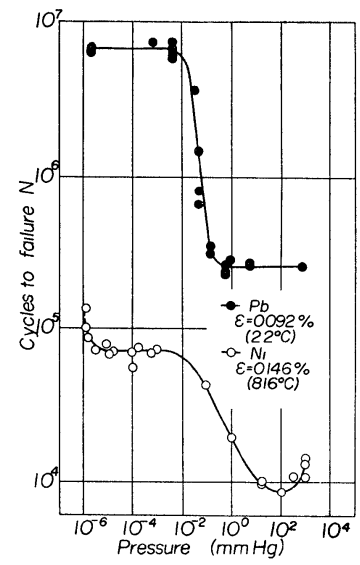

Fig. 6. Effects of atmospheric pressure on fatigue lives of nickel ${ }^{8)}$ and lead ${ }^{9}$.

8)9)

結果とがある，真空にして酸素を除く代わりに，不活 性ガス中で試験するととも行なわれているが，ガス中 の微量の不純物注意する必要がある。

ふん囲気ガスが影響をもつ原因を，酸化物の形成が サイクル中の圧縮時におけるき裂の再溶着を妨げるこ とにあると考光，き裂面がサイクルの引張りの間に吸 着するガス量を計算して，空気圧の影響にみられる飽 和点が実験とだいたい一致するととを述べた研究もみ られる。空中の湿度は害作用をもつといわれるが，酸 素の影響に比へて非常に小さいという実験結果が多い， 水蒸気が触媒作用を行なって酸素の作用を促進すると もいわれる。これらの影響がき裂の発生と進展のどち らに強いかも，結果はまちまちである。

筆者らは炭素銅 S 35C（焼なまし）を $99.99 \%$ 以上

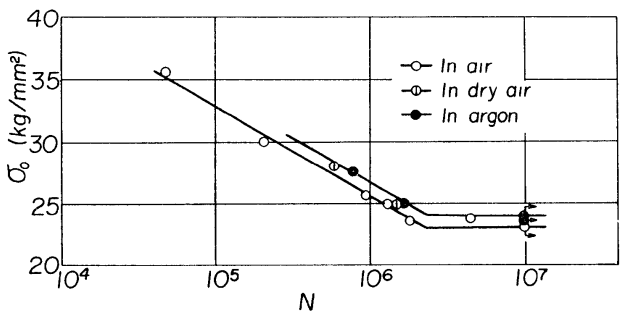

Fig. 7. $S-N$ curves of smooth specimens of $0.35 \%$ $C$ steel in gaseous environments under rotating bending $(n=2200 \mathrm{rpm}) .{ }^{11)}$
の純度のアルゴン中と， $2 \times 10^{-5}$ 以下の湿度の乾燥空 気中で回転曲げ疲労試験を行なった。平滑材の $S-N$ 曲 線を Fig. 7 亿示すように，酸素のほ加水蒸気も寿命 を短縮している。平滑材はき裂発生までの期間が長い ために，反応に比較的長時間を要する水蒸気の岺食作 用が現われやすいものと思われる。一方き裂発生期が ごく短く，ほとんどの寿命がき裂進展期による鋭い切 欠き材の場合，Fig. 8 亿みるように，水蒸気の効果は

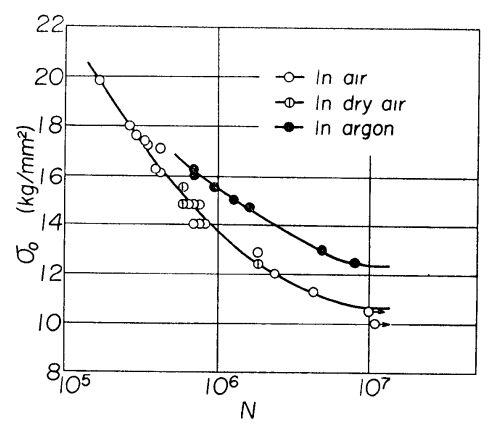

Notch depth : $085 \mathrm{~mm}$ Root radius of notch : $0.40 \mathrm{~mm}$

Fig. 8. $S-N$ curves of notched specimens of $0.35 \%$ $\mathrm{C}$ steel in gaseous environments under rotating bending ${ }^{11}$.

ほとんど現われず，大気中と乾學空気中とでは同一の 強度を示す．すなわち，大気中の水蒸気はき裂発生に 対しては害作用をもつが，き裂進展に及ぼす影響は小 さい，しかし， $\mathrm{Al}$ 合金， $\mathrm{Mg}$ 合金に対する平滑材の 試験結望と比べると, 鋼においては水蒸気の影響がか なり小さく，ての効果は材質によって異なるようであ る。

酸素の影響は Fig. 8 亿みたように，き裂進展に特に 著しい，さらに渦電流法によって，切欠き試験片のき 裂進展を非破壊で連続的に測定した結果を Fig. 9 亿示

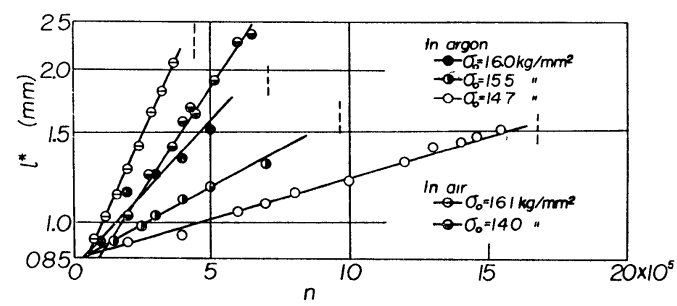

Fig. 9. Crack propagation of notched specimens of $0.35 \% \mathrm{C}$ steel in gaseous environments under bending ${ }^{11)} . l^{*}$ is the sum of notch depth $(0.85$ $\mathrm{mm}$ ) and crack depth.

す．図中 $l *$ は切欠き深さ $(0.85 \mathrm{~mm})$ とき裂深さの和 である.アルゴン中では空中に比べて著しくき裂進展 速度が小さい，酸素の化学吸着によってき裂面の表面 
エネルギが，アルゴンの物理吸着状態の約 $1 / 2$ 亿低下 し，き裂先端で塑性変形しやすくなっているととをて の原因と考觉た。乙れは疲労試験中ふん囲気を変えた ときのき裂進展を測定したFig.10からも考えられるて とである，アルゴンから大気変えたとき，ただちに 大気中固有のき裂速度に変化するが，大気よりアルゴ

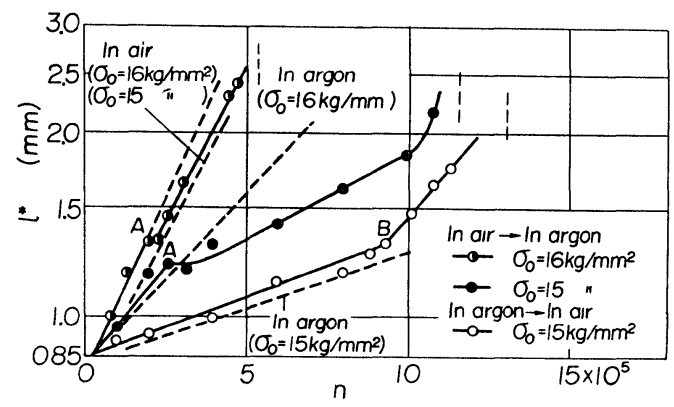

Fig. 10. Crack propagation in varying environments under rotating bending. Dormant stages are seen at $\mathrm{A}^{11)}$.

ンに変えたとき，き裂の進展に停留期がみられる。乙

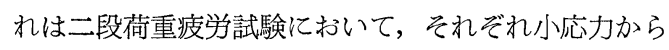
大応力へ，および大応力から小応力へ変化したときの き裂進展と似ており，見掛けの応力振幅は同じでも， 大気中ではアルゴン中より大きいひずみ振幅をき裂先 端で受けているととを推察させる.

油は空中の酸素, 水分をしゃ断して疲労寿命を延長 さすと考壳られるが，脂肪酸を含む油中での球軸受用 鋼の疲労強度は, Table I 亿示すょうに, 吸着のため 低下する結果が Rebinder によって得られている。 し かし一方，極性有機剤としてドデシルアルコールで鋼 その他の試験片面をおおうととによって，Fig.11亿示 すように，平滑材，切久き材ともに疲労寿命が空中よ り伸びる報告もある。強固な吸着膜が空中の酸素, 水 分の接近を防ぐてとによるとされている。しかし，て の被覆も水蒸気の防護に対して完全でなく、特にき裂 進展住する対す影響のほうが大きいという院もみられる

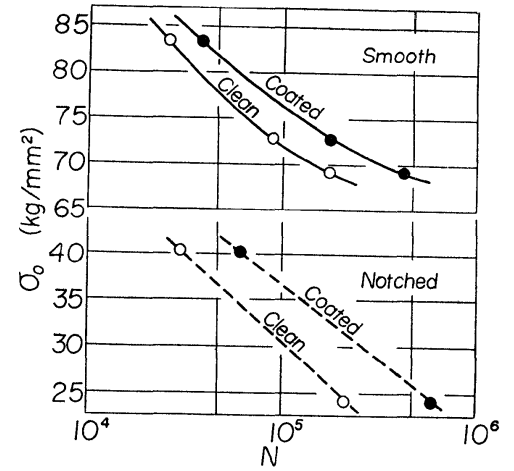

Fig. 11. $S-N$ curves of smooth and notched specimens of 4340 steel covered by dodecyl alcohol under rotating bending ${ }^{14)}$.

が，水蒸気の影響については前述のように疑問がもた れよう

Frost も 鉱油 (SAE30), ドデシルアルコール中で鋼 の回転曲げ疲労試験を行ない, 疲学寿命の増大を考察 して, ての効果はき裂進展に対して有効であり, 特に 鋭い切久きに対しては，水も酸素の接近を妨げるため， 油と同じ程度に寿命を増大させる結果を得ている。ま た，切久き平板の一軸疲労試験にてき裂進展を測定し， 試験片をブチルゴムで被覆したときも, 油中, 水中と ほぼ等しいき裂速度を得, また, 回転曲げ試験で油の 粘度を SAE 5 より90まで変化しても寿命に差がみら れなかったてとより, 液の流動性, 言い替光れば夜の くさび作用は影響せず，乙れらの効果は酸素のき裂先 端への接近が妨げられ，圧縮半サイクルの間でのき裂 面の再溶着が行なわれるととにあるとした。

同様に鈗油の粘度を変えて $\mathrm{Ni}$ 鋼の平滑試験片の回 転曲げ疲学試験を行ない, 粘度の影響はみられない結 果を得ているが, 平滑試験片ではき裂進展期はきわめ て短期であるので，てれからくさび効果の有無は論 ぜられない．同じ論文に脂肪酸添加の影響も試験され， 耐久限度が相当に低下するが，Au を被覆した試験片 では変化のないととより, 脂肪酸の効果は金属との化

Table I. Fatigue strength of Gr steels in lubricating oils under rotating bending ${ }^{2}$.

\begin{tabular}{|c|c|c|c|c|c|c|c|c|}
\hline$\sigma_{B}\left(\mathrm{~kg} / \mathrm{mm}^{2}\right)$ & \multicolumn{2}{|c|}{52} & \multicolumn{2}{|c|}{65} & \multicolumn{2}{|c|}{102} & \multicolumn{2}{|c|}{219} \\
\hline Medium & $\begin{array}{c}\sigma_{w} \\
\left(\mathrm{~kg} / \mathrm{mm}^{2}\right)\end{array}$ & $1 / K$ & $\begin{array}{c}\sigma_{w} \\
\left(\mathrm{~kg} / \mathrm{mm}^{2}\right)\end{array}$ & $1 / K$ & $\begin{array}{c}\sigma_{w} \\
\left(\mathrm{~kg} / \mathrm{mm}^{2}\right)\end{array}$ & $1 / K$ & $\begin{array}{c}\sigma_{w} \\
\left(\mathrm{~kg} / \mathrm{mm}^{2}\right)\end{array}$ & $1 / K$ \\
\hline Aır & 28.9 & 1 & 31.4 & 1 & 49.4 & 1 & 95.0 & 1 \\
\hline MS oll & 27.9 & 097 & 29.0 & 0.93 & & & 92.6 & 0.98 \\
\hline Used MS oll & & & 290 & 0.93 & & & & \\
\hline $\begin{array}{l}\text { MS oil, activated with } 0.2 \% \\
\text { oleic acid }\end{array}$ & 269 & 093 & 25.5 & 0.82 & 41.8 & 0.85 & 847 & 0.89 \\
\hline Castor o1l & & & & & 41.3 & 0.84 & & \\
\hline Grease & & & & & & & 89.9 & 095 \\
\hline
\end{tabular}


学反応によるものであると結論を下している.

筆者らの鋼試験による回転曲げの実験によれば，切 久き材のき裂進展速度は Fig. 12 にみるように, 空中 に比べて非常に小さくなり，酸素のしゃ断効果が明ら
られる。一般に油には相当な量の空気と水分が含まれ ている，そこで，脱気した後アルゴンを通じて不活性 にしたパラフィン油を用い，同じ切欠き試験片によっ て，アルゴン中で疲労試験をした結果，Fig. 14の $S-N$ 曲線にみるように，寿命は応力にかか わらず，アルゴン中より長くなり，き 裂速度がアルゴン中より常に低いこと が知られた。 さらに，ステアリン酸を 少量混ぜて試験すると，Fig. 13，14亿 示したようにき裂進展速度が低下し， 脱気油中とほぼ等しくなる，有極性脂 肪酸の吸着膜によって酸素の接近を防 ぎ，かつ油のくさび効果の現われたた めと考えられる。

この活性油中で平滑材の疲労試験を 行なうと, Fig. 15亿示すように, 耐久限 かであるが，さらに，使用した油の粘度が高いほどき 裂進展速度が減少しており，き裂内に浸入した油のく さび作用による圧縮側半サイクル中のき裂先端のひず み減少の効果が明らかである。乙のように, 油の効果 は酸素のしゃ断効果とくさび作用の和によるものであ るにかかわらず，応力によってはFig.13に示すように， アルゴン中よりき裂進展速度が高くなることがある。 てれは油中に含有されている酸素の影響のためと考え

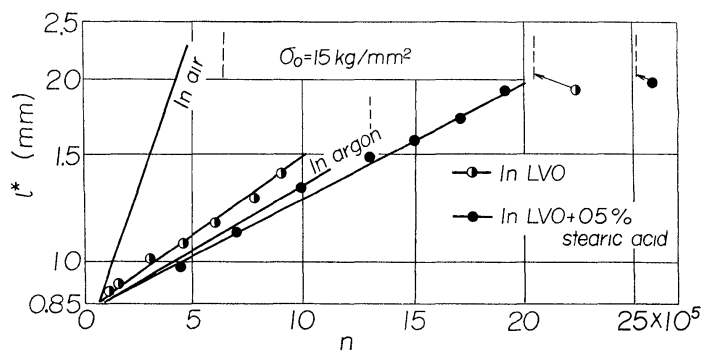

Fig. 13. Crack propagation of notched specimens in oil with and without stearic acid under rotating bending $(n=2200 \mathrm{rpm})^{18)}$.

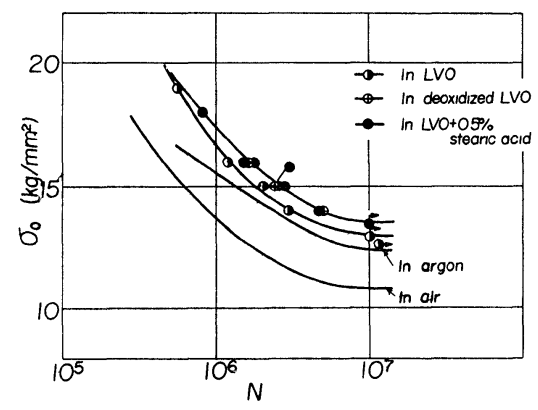

Fig. 14. $S-N$ curves of notched specimens of $0.35 \% \mathrm{C}$ steel in various oils under rotating bending ${ }^{18)}$.
度以上の寿命はやや伸びるようであるが，耐久限度は

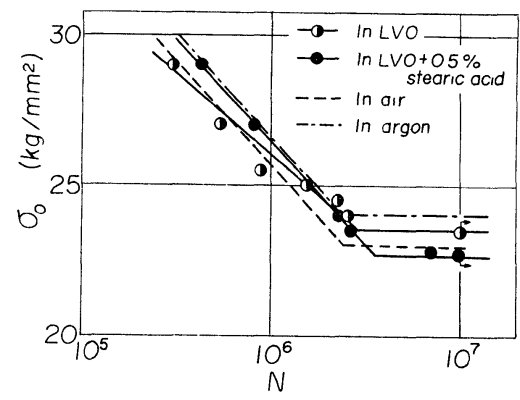

Fig. 15. $S-N$ curves of smooth specimens in oils under rotating bending $(n=2200 \mathrm{rpm})^{19}$.

無添加の油中より若干低下したことより, Rebinder 効 果はき裂発生の限界応力にきくと考えられる。特に切 欠き感度の高い焼入球軸受用鋼の平滑材にこの効果が 著しかったとともとのととを暗示するが，さらに研究 を要する。

表面疲労の一現象として，乙ろがり接触によるピッ チングがある。一般に油の粘度が高いほうが油膜作用 または幑小き裂への油の浸入しにくさのため寿命が長 くなるとされているが，Fig. 16に示すように必ずしも そうではなく，特に油の種類の影響が大きく，脂肪酸 では著しく短寿命である。 ての差は粘度の圧力指数に よっても説明できず，表面の化学反応を考えねばなら ない.ナフテン系の油のほうがパラフィン系の油より 寿命を長くするのは，前者のほうが熱的に安定で，反 応時に発生する水素によるぜい化の程度が少ないとと によるという説明もみられる。また，従来ピッチング に対しては Rebinder 効果を認めるような実験結果 が多かったが，物理吸着のみを行なら添加剤では強度 低下がみられなかったてとより，Rebinder 効果に疑 


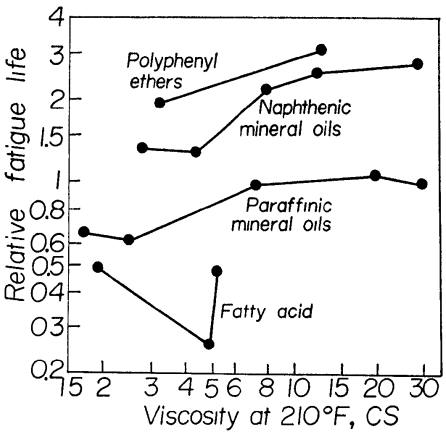

Fig. 16. Effects of oil viscosities on pitting lives of steel balls in various oils ${ }^{19}$.

問を提している

鈗油に水分を含むとき，Fig.17亿示すように，寿命 が著しく減少し，乙れを㵝食疲労と考えたり，水素ぜ い性の影響と考えたりされる１％の水分を含む鉣油 中で，油膜を介して電圧を加えた状態で試験した結果， アノード側にされたときは短時間のため腐食の効果が

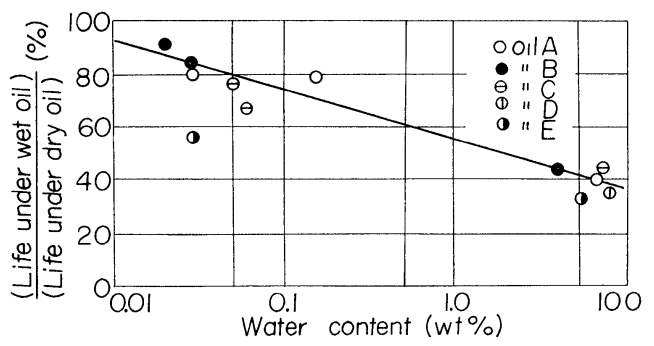

Fig. 17. Effects of water content in lubricating oil on pitting lives of steel balls ${ }^{22}$.

現われず，寿命の低下が認められなかったが，カソー ド側にされると寿命が $1 / 3$ 亿減少し，乙の原因を水素 ぜい性に帰している論文もある。

\section{4 腐 食 疲 労}

化学反応が進むとき，否食疲労の現象を生ずる，腐 食疲労の一般の疲労と異なる特色は，鉄鋼材料でも耐 久限度が認められず，応力繰返し速度の影響が大きい 点である、筆者らはさきに腐食効果 $k$ なる慨念を導入 してての問題を明らかにした。すすおち，ある称呼応 力 $\sigma_{c}$ で窗食疲学試験を行なうと，ピット，き裂の応 力集中により真応力は $\sigma_{c} k$ となり，乙の応力が空中 の疲労強度に達したとき破損を生ずるとすると，Fig. 18,19 亿示す $S-N$ 曲線， $S-t$ 曲線の説明図にみられ るように，任意の繰返し速度，指定繰返し数における 強度を知りえ，また各種の組合せ応力における強度も 説明される. ここで $k$ は一般には時間の関数であるが， ときには繰返し速度も影響してくる。しかし，てれら の研究に用いた応力波形は正弦波状のため, 繰返し速

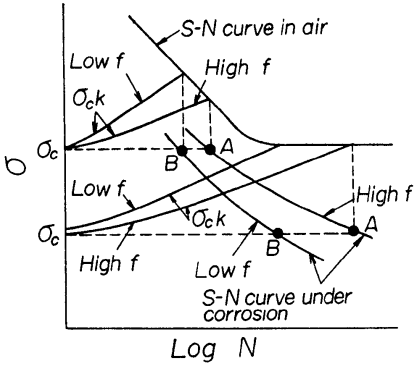

Fig. 18. Schematic diagram of frequency effects on $S-N$ curves under corrosion fatigue ${ }^{24)}$.

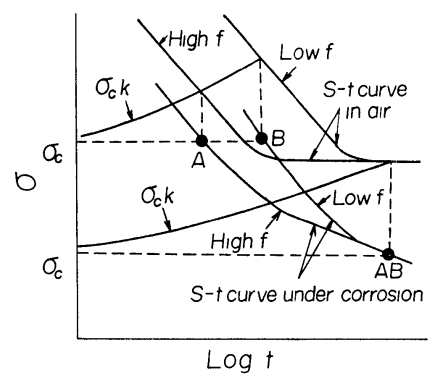

Fig. 19. Schematic diagram of frequency effects on $S-t$ curves under corrosion fatigue ${ }^{24)}$.

度が変化すると，所定の繰返し数を与光るに要する時 間とともに，ひずみ速度も変化する，そのため，腐食 効果に及ぼす繰返し速度の影響の由以が明らかでない， また，非常な低サイクルまでこの考え方が成立するか 疑問である。

筆者らはFig. 20に示すような台形状の応力波形を用 い，繰返し速度にかかわらずひずみ速度を規定しうる
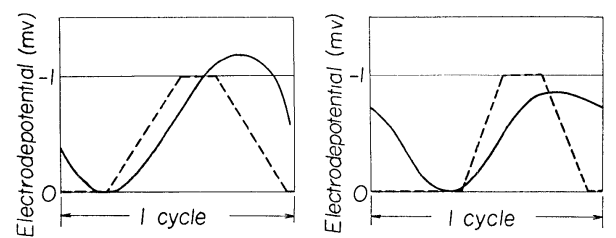

Fig. 20. Electrodepotential varying in a cycle of stress wave shown by a dotted line ${ }^{26}$ ).

試験を行ないサイクルトの電位の変動をあわせて測 定した。図は 1 サイクル $7.3 \mathrm{sec}$ の例であるが，電位 はひずみの変動より痋れて変化し，応力波形が台形状 でも，電位変化は正弦波に近い肜をとり，备サイクル においてわずかずつ卑方向へのずれを示す。

したがって，速度効果は応力が上昇，下降している 間の時間に最も強く影響される。高応力に保持されて いる間に電位が貴方向に回復する材料（たとえば高力 $\mathrm{Al}$ 合金）と，しない材料（たとえば高力鋼）とがあ り，それぞれ高応力保持時間の寿命に対する影響の出 
かたが異なる。また前者では，各サイクルにおける電 位のずれがなく，応力繰返し数に伴う電位は初めから ほとんど一定であるが，後者では各サイクルにおける 電位のずれが蓄積されるので, 応力繰返しに伴って電 位が卑になっていく。

また，倠食疲労における平均応力の影響は電位の平 均值の変化として現われることが知られ，さらにある 程度以上応力繰返し速度が小さくなり, 電位が応力波 形に完全に追随するようになると, 否食疲労における 速度効果が現われなくなることが知られた。

以上は主として電位に対する考察であるが，腐食に よるき裂先端の鈍化，き裂に対する切欠き効果のき裂 速度への影響が含まれ, 前述の腐食効果 $k$ と関連され る。定量的に規定できる段階に達していないが，定性 的に充分説明できるようになった。

\section{5 摩 耗その他}

摩擦と表面エネルギの関係についてはさきに簡単に 述べたが，摩耗もまた表面エネルギと結びつけて考え られている．二面が接触するとき真の接触面積は見掛 けのそれに比べて非常に小さいものであり, その圧力 は高い．接触部は凝着し，一方の金属より他方の金属 面へ転移し，乙れがいわゆる凝着摩耗の原因である。 ての凝着して転移した金属が摩耗粉となって脱落する 機構として，次のようなととがいわれている。

Rabinowicz は転移した金属在半球状と仮定し，乙 れにたくわえられた弾性エネルギが，転移片が母材に 凝着するエネルギ $U_{a b}$ をてえるときに摩耗粉になる としたとれより簡単な辣算により $d=60000 U_{a b} / H$ で摩耗粉の大きさ $d$ を得た，種々の金属および少数の 非金属について同質摩耗試験を行なって，摩耗率とか たさHとの間には簡単な関係が認められないが，摩耗 粉直径と $U_{a a} / H$ の関係は, Fig. 21 に示すように, 上 式とよく一致しているてとを示している。異種摩耗を 行なうと, 凝着仕事 $U_{a b}$ は一般に $U_{a a}$ より小さいの で, 摩耗粉は小さくなる。また, ふん囲気を変えて試 験を行なうと, Table II 亿示すように，表面エネルギ が吸着によって低下されたとき摩耗粉が小さいととを 確かめ，潤滑油による摩耗粉の微細化を説明している.

摩耗の別の形態としてアブレシブ摩耗がある. 介在 する固い物体または固くてあらい面による切削に近い 摩耗をいう。 Kuznetsov はぜい性材料のアブレシブ摩 耗において，摩耗粉を作るに要する仕事として，U= $F L=\beta / \alpha \cdot V \gamma$ を得ている. ここに $F$ は摩擦力, $L$ は 走行距離であり， $\alpha$ は全仕事のうち表面エネルギ増大 に対する仕事の割合で $10^{-7}$ の程度の小さい価， $\beta$ は粉 末の寸法に関連した価，Vは摩耗容積である。乙れは， たとえば表面凹凸を片持ばりと考え, 最大応力が弓張 炤和 42 年 11 月

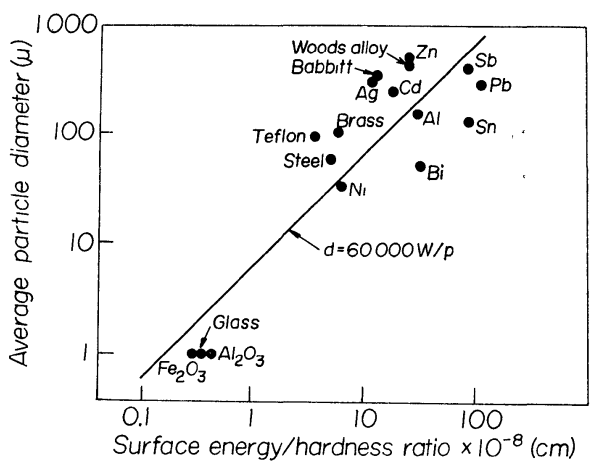

Fig. 21. Diameter of wear particles and work of adhesion/hardness ratio ${ }^{1)}$.

Table II. Size of copper wear particles in various environments ${ }^{1}$.

\begin{tabular}{l|c}
\multicolumn{1}{c|}{ Environment } & $\begin{array}{c}\text { Average fragment diameter } \\
(\mu)\end{array}$ \\
\hline Nitrogen & 480 \\
Helium & 380 \\
Carbon dioxide & 300 \\
Dry air & 224 \\
Oxygen & 201 \\
Laboratory air & 177 \\
Wet air & 144 \\
Cetane & 12.0 \\
Silicone DC 200-100 cst & 9.5 \\
Ucon fluid I.B-70X & 9.5 \\
Palmitic actd in cetane & 80 \\
\hline
\end{tabular}

強度 $\sigma_{B}$ 亿達するまでの弾性仕事と, $a$ なる原子間距 離における表面エネルギ $\gamma=a \sigma_{B}^{2} / 2 E$ とを組み合わせ て得られるものである。 2 個の結晶で $\alpha, \beta$ が等しい とき， $F_{1} L_{1} / F_{2} L_{2}=V_{1} \gamma_{1} / V_{2} \gamma_{2}$ であり，荷重を適当潠 んで $F_{1}=F_{2}$ で試験すると, 同じ走行距離 $L_{1}=L_{2}$ に おいて， $V_{1} / V_{2}=\gamma_{2} / \gamma_{1}$ によ，摩耗量は表面エネルギ と逆比例する．エメリ紙によるアブレシブ摩耗でての ことを証明している。また立方晶の岩塩において，へ き開は (100)面で生ずるが，その仕事 $U_{1}$ と，(110) 面 および (111) 面で分割するに要する仕事 $U_{2}, U_{3}$ との 比は，へき開面の面積比より $U_{1}: U_{2}: U_{3}=1: \sqrt{2}$ : $\sqrt{3}$ が得られ, 各面をアブレシブ試験するとき, 実験 とよく合うことを述べている。最も簡単なのは 2 種の 材料在互いに摩擦させ，したがって $F_{1}=F_{2}$ として， このときの摩耗量を表面エネルギの評洒に適用するこ とを提案している。

このように，摩耗と表面エネルギを関連させる考え 方は，摩耗を一種の表面疲労とする考え方に導く、筆 者らは摩耗率の逆数と摩耗力の間に，Fig. 22に示すよ 


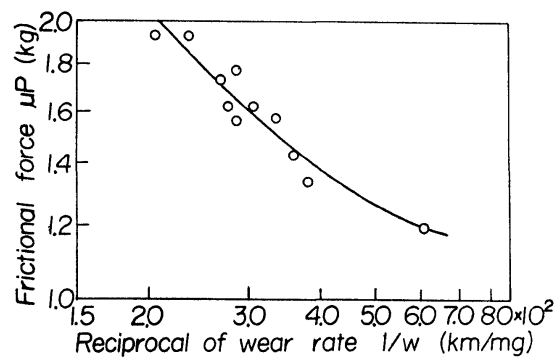

Fig. 22. Relation between frictional force and reciprocal of wear rate under lubricating wear tests of a carbon steel ${ }^{31}$.

うに, 疲労の $S-N$ 曲線と類似した関係を得ている. 摩 耗率の逆数は摩耗粉を発生するに要する摩擦力の繰返 し数に相当する。乙の図は疲労試験におけるき裂進展 速度と, 称呼応力との間に得られる線図と似た意味を もつと考光られる。た, 試験の途中で荷重を増減し たときの摩耗量の変化は, Fig. 23に示すように, 大荷

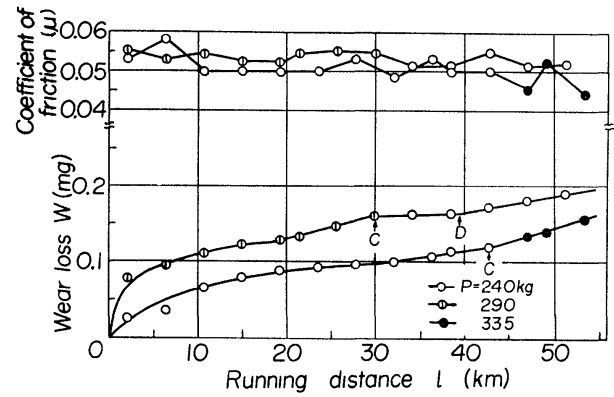

Fig. 23. Wear curves under varying loads. Dormant stage CD is seen under high-low load ${ }^{32)}$.

重より小荷重に変化した $\mathrm{G}$ 点で $\mathrm{D}$ 点までの摩耗の停留 期がみられ, 小荷重より大荷重に変化した G 点では停 留期が存在せず, さきに述べた変動荷重における疲労 き裂の進展曲線と酷似した模様を示している。

Sibley らが球軸受の寿命に対する Palmgren の式 を用いて，機械要素の摩耗量を定量的に求めることを 提案しているのは, 摩耗を疲労の現象としたものであ る.

筆者らはまた，アブレシブ摩耗を塑性疲労の現象で あると考光て，その抵抗が $H^{3} / E^{2}$ または $H^{2} / E^{2}(H$ は かたさ，Eは弾性係数）に比例することを導いた． こ れは Oberle が，別の考え方より，H/E または $H^{2} / E$ を modell factor とよんで, 摩耗抵抗を表わす值と しているのと一致する.

ころがり接触によるピッチングの而久限度が $H^{2} / E$ に比例するだろうことは，ピッチングが Hertz 応力 の繰返しによる疲労であることより当然考えられるて とである.キャビテーション気泡の崩壊圧の繰返しに
よるエロージョン抵抗として, Glikman の実験結果 より重量減少率の逆数をとり，材料の $E$ を推定して $H^{2} / E$ との関係を求めると，Fig. 24亿示すように，ほ

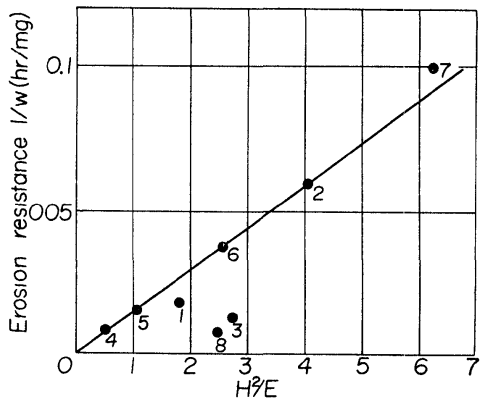

\begin{tabular}{|c|c|c|}
\hline & $H_{B}$ & $E\left(\mathrm{~kg} / \mathrm{mm}^{2}\right)$ \\
\hline 1. Brass & 103 & $0.63 \times 10^{4}$ \\
\hline \multicolumn{3}{|l|}{ 2. Manganese-iron } \\
\hline -aluminıum-brass & 217 & 105 \\
\hline 3. Modified cast iron & 197 & 140 \\
\hline 4. $\mathrm{S} 10 \mathrm{G}$ & 107 & 2.07 \\
\hline 5. $\mathrm{S} 31 \mathrm{C}$ & 153 & 2.10 \\
\hline 6. Stainless steel & 229 & 2.10 \\
\hline 7. Ni-Cr-steel & 368 & 210 \\
\hline 8. Grey cast iron & 187 & 140 \\
\hline
\end{tabular}

Fig. 24. Relation between cavitation damage and $H^{2} / E$ obtained from test results by Glikman ${ }^{36)}$.

ぼ比例関係が得られるのは興味がある。ただし，鋳鉄 はその組織の不均一性とキャビテーションの局部性の ため，てれに当てはまらない，さらに，てれらの強度 が表面性質，ふん囲気と密接な関係にあるだろうこと は想像にかたくない。

平軸受，乙ろがり軸受，歯車などのように，二面が 液中で急速に接近，離反を繰り返す場合は，キャビテ ーション・エロージョンだけでなく，二面間のスクィ ズ・フィルム作用に伴う液の流出, 流入による表面摩

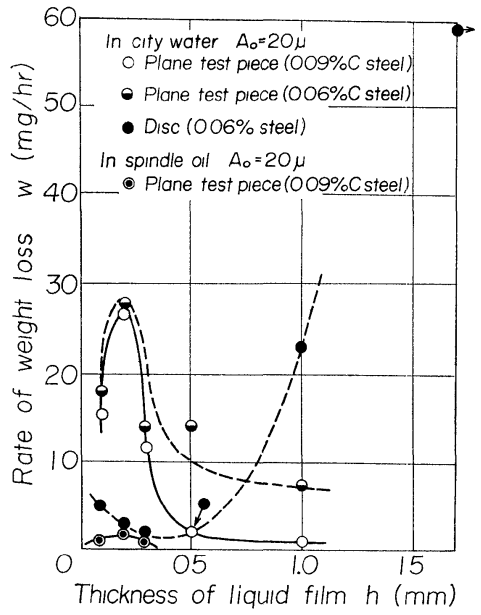

Fig. 25. Weight losses of unmoved specimens and of specimen oscillating with various thicknesses of liquid film ${ }^{37)}$. 
擦の繰返しによって，表面に疲労椇傷を生ずる。水中 で鋼平板に対して鋼円板を振動させたときの，二面間 のすきまと損傷度の関係をFig. 25亿示す．静止平板と 振動円板とでは損傷の程度に差があるが，ともにすき まが大きい間はキャビテーション・エローショョンによ り，また，すきまが非常に小さくなると液の繰返し摩 擦による疲労被害を生ずる。

ライニングした軸受用銅・鉛合金を平板試験片とし て油中で試験した結果をFig. 26亿示す。す すきまが小さ

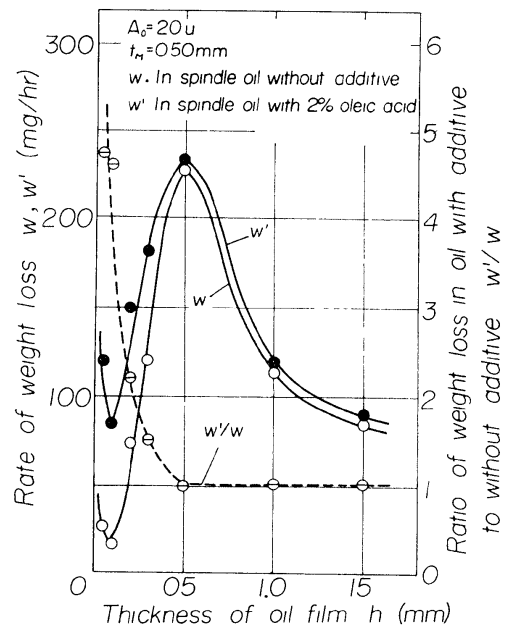

Fig. 26. Weight loss of unmoved specimens of Cu-

$\mathrm{Pb}$ bearing alloy due to vibration of opposite disc in lubricating oils ${ }^{38)}$.

いとき，明らかに表面疲労による損傷の増大が認めら れる。乙の損傷は重量減少量としては大きいものでな いが，き裂を生じてメタルのはく離に至る危険なもの である、オレイン酸を $2 \%$ 含ませた油中では，キャビ テーション・エロージョンの範囲内ではその影響は大 きくないが，流体摩擦の疲労の範囲で急激に影響が増 大し，乙とにも吸着の表面疲労に及ぼす影響が明らか にみられる。

\section{6 結言}

材料表面の仕上程度, 加工首, 残留応力のような機 械的性質は当然であるが，その物理的，化学的状態と ふん囲気が材料の強度, 特に疲学強度に大きい影響を もつことを述べた．各種の表面損賃を疲労の現象とし て，てれに及ぼす表面エネルギ，ふん囲気の影響をと り入れて考えるととによって，種々の現象が説明され， また興味深い問題が提起される。

(昭和 42 年 5 月 23 日 日本材料学会第 16 期総会にて講演)

\section{参 考 文 献}

1) Rabinowicz, E., "Friction and Wear of Materials" (1965) John Wiley and Sons.
2) Likhtman, V.I., P.A. Rebinder, and G.V. Karpenko, Effect of a Surface-Active Medium on the Deformation of Metals (1958) Her Majesty's Stationery Office.

3) Bowden F.P., and D. Tabor, Properties of Metallic Surfaces, Inst. of Metals, p.197 (1953).

4) Shaw, M.C., J. Appl. Mech., 15, 37 (1948).

5) Grosskreutz, J., J. Appl. Phys., 33, 2653 (1962).

6) Holshouser, W.L., and J.A. Bennett, Proc. AS TM, 62, 683 (1962).

7) Wadsworth N.J., and J. Hutchings, Phil. Mag., 3, 1154 (1958).

8) Achter, M.R., G.J. Danek, and H.H. Smith, Trans. ASME, 227, 1296 (1963).

9) Snowden, K.U., Nature, 189, 53 (1961).

10) Gough, H.J., and D.G. Sopwith, J. Inst. Metals, 72, 415 (1946).

11）遠藤吉郎，駒井謙治郎，日本機械学会論文集， 244, 1800 (1965).

12) Bennett, J.A., Mat. Res. \& Standards, 3, 480 (1963).

13) Hudson C.M., and H.F. Hardrath, NASA TN D-960 (1961).

14) Holshouser, W.L., and H.P. Utech, Proc. AS TM, 61, 749 (1961).

15) Shives, T.R., and J.A. Bennett, NASA CR-267 (1965).

16) Frost, N. E., NEL Report, No. 89 (1963).

17) Galvin, G.D., and H. Naylor, Proc. Inst. Mech. Engrs., 179, 857 (1964).

18) Endo, K., and K. Komai, JSME 1967 SemiInternational Symposium Papers, 1, 97 (1967-9).

19) Rounds, F.G., Jr., "Rolling Contact Phenomena", 346 (1962) Elsevier Publishing Co.

20) Grunberg, L., D.T. Jamieson, and D. Scott, Phil. Mag., 8, 1553 (1963).

21) Rounds, F.G., ASLE Paper, No.66 LG-27 (1966).

22) Grunberg, L., and D. Scott, J. Inst. Petro., 49, 406 (1958).

23) Syniuta, W.D., The Origin of Microcracks Leading to Rolling Contact Fatigue, Surface Laboratory, MIT, Research Report No. 35 (1966).

24）遠藤吉郎，宮尾義治，日本機械学会論文集，24， 167 (1958).

25）遠藤吉郎，宮尾義治，Proc. 1st Japan Cong. on Test. Materials, p. 17 (1958).

26）遠藤吉郎，駒井謙治郎，材料， 13，536（1964）.

27）遠藤吉郎，駒井謙治郎，材料， 14，827（1965）. 


\begin{tabular}{ll} 
遠 藤 吉 郎 \\
\hline
\end{tabular}

28）遠藤吉郎，駒井謙治郎， Proc. 9th Japan Cong. on Test. Materials, p. 25 (1966).

29）遠藤吉郎, 駒井謙治郎, 中垣邦弘, 日本機械学会 諭文集，34（1968-1）掲載予定.

30) Kuznetsov, V.D., Surface Energy of Solids (1957) Her Majesty's Stationery Office.

31）遠藤吉郎, 福田嘉雄, Proc. 8th Japan Cong. on Test. Materials, p. 69 (1965).

32) 遠藤吉郎, 福田嘉雄, 豊田洋民, 日本機械学会講 演前刷集，No.168，125（1967）。

33) Sibley, L.B., and G.M. Allen, Wear, 5, 312
(1962).

34）遠藤吉郎, 福田嘉雄, 工藤 忠, 日本機械学会論 文集，32，526（1966）。

35) Oberle, T.L., J. Metals, 3, 438 (1951).

36) Glikman, L.A., Gorrosion-Mechanical Strength of Metals, Butterworths (1962).

37）遠藤吉郎, 岡田庸敬, 中野達也, 中島政明, 日本 機械学会論文集, 32,831（1966）.

38）遠藤吉郎, 岡田庸敬, 中島政明, 日本機械学会論 文集，33，1515 (1967). 